\title{
Localization of zearalenone detoxification gene(s) in pZEA-1 plasmid of Pseudomonas putida sp. strain ZEA-1 and expressed in Escherichia coli
}

\author{
Altalhi, A.D. and El-Deeb, B.* \\ Taif University, Faculty of Science, Biological Science Department, P.O.888, Taif, Kingdom of Saudi Arabia \\ E-mail: bahig56@yahoo.com
}

\begin{abstract}
The gene(s) encoding enzyme(s) involved in the initial reaction during degradation of zearalenone was characterized from the zearalenone utilizer Pseudomonas putida strain ZEA-1, in which ZEA transformed into product with less or not toxic. A 5.5 kilobase-pair (kpb) Pst1-Kpn1 fragment containing gene(s) coding for zearalenone degradation was cloned. The cloned gene(s) activity was expressed in Escherichia coli, and ZEA degradation by recombinant E. coli was relatively rapid and effective, leaving no detectable ZEA after $72 \mathrm{~h}$. In further experiments, cell-free extract of E.coli have been used in the same way, both to confirm these observations and the enzymatic nature of the degradation activity.
\end{abstract}

Keywords: DNA Cloning, E. coli, Zearalenone, biotransformation, Pseudomonas sp. Artemia salina

\section{INTRODUCTION}

Zearalenone (ZEA) [6-(10-hydroxy-6-oxo-trans-1undecenyil)-resorcylic acid lactone] is a mycotoxin produced by several species of Fusarium, most notably Fusarium graminearum and F. culmorum. Zearalenone and its derivatives exert estrogenic and anabolic effects on mammals. Carryover of zearalenone from infected grain to feedstuff causes reproductive problems in pigs, sheep, and other farm animals including precocious sexual development, vulva enlargement pseudopregnancy, loss of embryos, and reduced litter size (Farnworth and Trenholm, 1983; Long and Diekman, 1986; Green et al., 1990). When digested with grainbased food, zearalenone may cause hyperestrogenism in children (Szuetz et al., 1997)). A part from its estrogenicity, zearalenone is genotoxic in mice and is a suspected carcinogen (Coe et al., 1992; Grosse et al., 1990; Pfohl-Leszkowicz et al., 1995). Hence; increasing attention has been paid to the development of an effective strategy for the decontamination of ZEA. Although numerous physical and chemical detoxification methods have been tested, none really fulfills the necessary efficacy, safety, and cost requirements (Ruy et al., 2002). Therefore, the development of biological detoxification measures, especially in traditionally developed countries fermented food products, is essential to improve the safety of these foods for human consumption (Sweeney and Dobson, 1999). Several studies based on adsorption to appropriate media are currently being developed. For example, food grade Lactobacillus strains were useful for removing a certain amount of ZEA by binding to the cell surface (El-Nezami et al., 2002). However, other tools are also needed for the development of a more efficient and reliable method.

Enzymatic detoxification could be an efficient method for ZEA detoxification (Megharaj, 1997, Varga, 2005; Smiley and Draughon, 2004; Utermark and
Karlovsky, 2007). Kakeya et al. (2002) previously found that ZEA is converted to a far less estrogenic product on incubation with a fungal strain of Clonostachys rosea. The hydrolase responsible for detoxification was purified to homogeneity and its gene (designated Zhd101) was subsequently isolated (Takahashi-Ando et al., 2002, 2004). Recently, we isolated a Pseudomonas putida ZEA-1 (pZEA-1) strain in our laboratory, which can rapidly transform/detoxify the zearalenone. An enzyme capable of transforming a zearalenone and its derivatives, including $\alpha$-zearalenone and $\beta$-zearalenone was expressed by genes borne on the large plasmid. We now report the molecular cloning of the gene(s) that encodes this zearalenone transforming enzyme(s).

\section{MATERIALS AND METHODS}

Mycotoxin, Zearalenone, $\alpha$-zearalenol and $\beta$-zearalenol were purchased from Sigma Chemical Company (St. Louis, MO). All chemicals were at least of analyticalreagent. Each mycotoxin was dissolved in DMSO $(10 \mathrm{mg} / \mathrm{mL})$ and used as a standard stock solution.

\section{Bacterial strains, plasmids, and media}

The bacterial strains and plasmids used are listed in Table 1. E. coli DH5a was used as the host strain for construction and maintenance of recombinant plasmids containing zea degradation genes. E. coli BL21 (DE3) (Novagen,Masison, WI, USA) was used for expression of the zea genes. E. coli strains harboring recombinant plasmids were grown at $37^{\circ} \mathrm{C}$ in $50 \mathrm{~mL}$ LB (Luria broth) medium $(5 \mathrm{~g}$ yeast extract, $10 \mathrm{~g}$ trypton, and $10 \mathrm{~g} \mathrm{NaCl}$ in $1 \mathrm{~L}$ distilled water containing ampicillin (Ap) $50 \mu \mathrm{g} / \mathrm{mL}$ ). Selection minimal salt medium (MSM) utilizing $100 \mu \mathrm{g} / \mathrm{ml}$ zearalenone as a sole carbon source contained the following gram per liter: $(\mathrm{NH} 4)_{2} \mathrm{SO}_{4}, 0.5 ; \mathrm{MgSO}_{4} .7 \mathrm{H}_{2} \mathrm{O}$ $0.2 ; \mathrm{CaCl}_{2}, 0.05 ; \mathrm{Na}_{2} \mathrm{HPO}_{4}, 2.44$, and $\mathrm{KH}_{2} \mathrm{PO}_{4}, 1.52$. For 
plate cultures, the media mentioned above, solidified with $1.6 \%(\mathrm{wt} / \mathrm{vol})$ agar, were used. The $\mathrm{pH}$ was adjusted to
6.8 and the medium was sterilized prior to the addition of organic substrates.

Table 1: Bacterial strains and plasmids used in this study

\begin{tabular}{|c|c|c|}
\hline $\begin{array}{l}\text { Strain or Plasmids } \\
\text { Bacterial strains }\end{array}$ & Characteristics & Source \\
\hline P. putida ZEA-1 & Zearalenone degrading soil isolate $\left(\right.$ zea $\left.^{+}\right)$ & $($(El-Deeb,2005) \\
\hline P. putida ZEA-1 & Plasmid-cured derivatives of $P$. putida ZEA-1 (zea-) & Altalhi, 2007 \\
\hline E. coli DH5a & $\begin{array}{l}\text { SupE44 delta Lac U169 (Phi80Lac delta M15 hasd R17 } \\
\text { RecA19 yrA 96 Thi-1relAt }\end{array}$ & Gibco,BRL \\
\hline E. coli BL-21(DE3) & Expression vector host & Noagene \\
\hline Plasmids & & \\
\hline pUC18 & pMB1 replicon, LacZ' Ap ${ }^{r}$ & 32 \\
\hline pUC19 & pMB1 replicon, LacZ' Ap ${ }^{r}$ & 32 \\
\hline pET5a & Expression vector & Novagene \\
\hline pZEA-1 & Plasmid isolated from $P$. putida ZEA-1, $120 \mathrm{~kb}$ & Altalhi,2007 \\
\hline pZEA-2 & $\begin{array}{l}\text { 8.6 kb BamH1 fragment insert of pZEA-1 insert cloned into } \\
\text { pUC18 }\end{array}$ & This study \\
\hline pZEA-3 & 8.6 kb BamH1 fragment insert of pZEA-1 cloned into pUC19 & This study \\
\hline pZEA-4 & 5.5-kb Pst1-Kpn1 fragment insert cloned in pUC18 or pUC19 & This study \\
\hline pZEA-4a & $\begin{array}{l}\text { 5.5-kb Pst1-Kpn1 fragment insert cloned from pUC18 into } \\
\text { expression vector pET5a }\end{array}$ & This study \\
\hline pZEA-4b & $\begin{array}{l}\text { 5.5-kb Pst1-Kpn1 fragment insert cloned from pUC19 into } \\
\text { expression vector pET5a }\end{array}$ & This study \\
\hline pZEA-5 & $\begin{array}{l}\text { 3.2-Kb BamH1-Xba1 fragment fragment insert cloned in } \\
\text { pUC18 or pUC19 }\end{array}$ & This study \\
\hline pZEA-6 & $\begin{array}{l}\text { 4.2-Kb Sph1-BamH1 fragment fragment insert cloned in } \\
\text { pUC18 or pUC19 }\end{array}$ & This study \\
\hline pZEA-7 & $\begin{array}{l}4.2 \mathrm{~Kb} \text { BamH1-Sph1 fragment fragment insert cloned in } \\
\text { pUC18 or pUC19 }\end{array}$ & This study \\
\hline pZEA-8 & $\begin{array}{l}3.9 \text { EcoR1 fragment fragment insert cloned in pUC18 or } \\
\text { pUC19 }\end{array}$ & This study \\
\hline
\end{tabular}

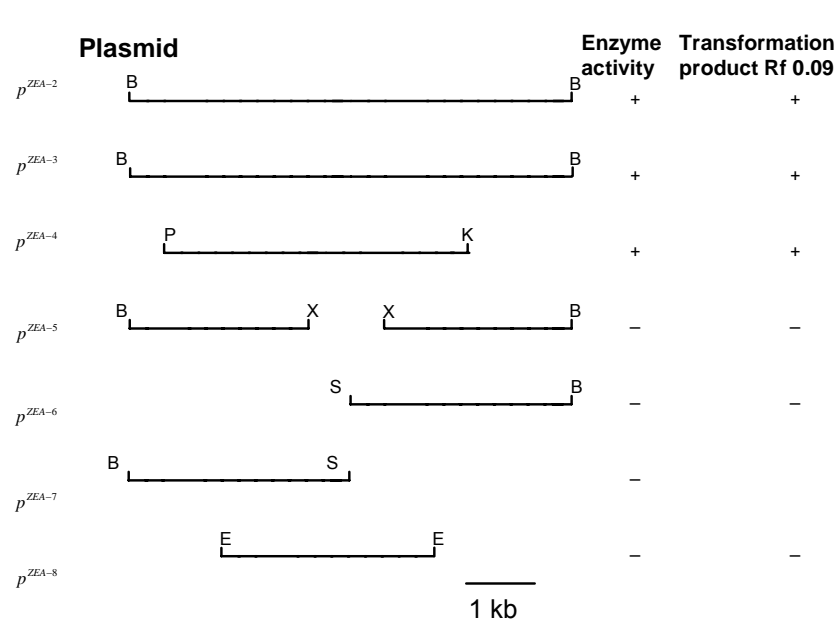

Figure 1. Cloning of DNA fragments of pZEA-1 in E. coli, using the vector pUC19 or-18 and localization of the zeadegradation gene(s). pZEA-1 fragments that when ligated into pUC19-or 18 indicated on the left. At the right are shown the phenotypes of $E$. coli DH5a harboring these plasmids, + , Growth on zearalenone (ZEA) and transform it to a new product $\left(R_{f} 0.09\right)$; -, no growth. Relevant restriction sites of the pZEA-1 used for cloning: B, BamH1; E, EcoR1; P, Pst1; X, Xba1, and K, Kpn1. 


\section{Analysis of zearalenones}

Concentration of zearalenone in culture broth was evaluated by high-performance chromatograph analysis as described by (Utermark and Karlovsky, 2007). Reverse-phase high-performance liquid chromatography (HPLC) with a diod array and mass spectrometric detectors was used. The column was a Polaris C18-A (5 $\mu \mathrm{m}, 150$ by $\mathrm{nm}$; Varian, Darmstadt, Germany), the mobile phase was $55 \%$ methanol- $45 \%$ water- $5 \%$ acetonitrile, the flow rate was $0.2 \mathrm{~mL} / \mathrm{min}$, the column temperature was $40{ }^{\circ} \mathrm{C}$, detection was done with a diod array detector (absorbance at 200 to $800 \mathrm{~nm}$ ), and mass spectrometry was done by electrospray in positive mode (scan for a mass/charge ratio of 250 to 500). Preparation of sample was done by extracting culture supernatants with ethyl acetate and removing the solvent on a rotary evaporator. The residue was dissolved in the mobile phase. A five point calibration curve $(0.05 ; 0.1 ; 1.0 ; 10.0$ and 20.0 $\mathrm{ng} / \mathrm{mL}$ ) was prepared with standards of zearalenones (Sigma) and regularly checked. The degradation of zearalenone was quantified in equivalents of zearalenone using the previous calibration curve.

Thin layer chromatography (TLC) was used for qualitative analysis of zearalenone metabolities. Merk silica gel 60 F254 plates (thickness, $0.25 \mathrm{~nm}$ ) were developed with solvent system (chloroform/acetone $(80: 20 \mathrm{vol} / \mathrm{vol})$. Metabolities were visualized under irradiation and the major metabolities were recovered from TLC plates by elution with ethyl acetate.

\section{Preparations, analysis, and cloning of DNA}

Plasmid DNA was isolated by the procedure of Kado and Liu (1981) in Pseudomonas strains and by Maniatis et al. (1982) in E. coli. Cloning and analysis of clones were carried out as previously described (Sambrook et al., 1989), with specific procedures described below.

Total plasmid DNA, isolated from Pseudomonas putida strain ZEA-1, was digested with restriction endonuclease BamH1 and ligated to the positive selection cloning vector, pUC19 (Yanish-Perron et al., 1985). Recombinant plasmids were used to transform $E$. coli DH5a, which was then spread on ampicillin-LB agar plates. Following overnight incubation at $37{ }^{\circ} \mathrm{C}$, transformants were picked and subsequently screened for inserted fragments and zearalenone degradation. Several subclones were generated by cloning onto pUC19 or 18 to locate precise region of zea degradation genes. The enzymes EcoR1, Pst1, Sph1, Xba1, and Kpn1 and T4 DNA ligase were used for subcloning of different DNA fragments.

Biotransformation of Zearalenone by crude enzyme of recombinant $E$. coli

Expression studies were carried out using E. coli BL-21 (DE3) carrying pZEA-4a. One colony from freshly transformed cells was used to inoculate $2 \mathrm{~mL}$ medium containing $50 \mu \mathrm{g} / \mathrm{mL}$ ampicillin. Optimal production of recombinant protein (enzyme) was obtained when midexponential phase cells $(\mathrm{OD} 600=0.6)$ were induced with $0.4 \mathrm{mM}$ IPTG or ZEA $(100 \mu \mathrm{g} / \mathrm{mL})$ for $5 \mathrm{~h}$ at $37^{\circ} \mathrm{C}$. Cell of Pseudomonas putida strain ZEA-1 (pZEA-1), grown in LB or Zea, were harvested in a similar manner. Then the cells were harvested by centrifugation $(5,000 \times \mathrm{g}, 10 \mathrm{~min}$, and $\left.4{ }^{\circ} \mathrm{C}\right)$, washed twice with $10 \mathrm{mM}$ Tris- $\mathrm{HCl}(\mathrm{pH} 7.6)$ and resuspended in 0.01 volume of the same buffer. The cells were then disrupted with a sonicator and centrifuged at $12,000 \times g$ for 20 min to obtain the supernatant (crude enzyme fraction). Enzyme assays were initiated by the addition of $100 \mu \mathrm{L}$ of the crude enzyme fraction to a reaction mixture containing $3.66 \mathrm{~mL}$ of $10 \mathrm{mM}$ Tris- $\mathrm{HCl}$ $(\mathrm{pH}$ 7.5), $200 \mu \mathrm{L}$ of zearalenone in $50 \mathrm{~mL}$ ethanol $(100$ $\mu \mathrm{g} / \mathrm{mL})$. The mixture was incubated in the dark at $30{ }^{\circ} \mathrm{C}$ without shaking. At selected times, samples were centrifuged at $10,000 \times g$ for $5 \mathrm{~min}$, filtered through 0.2 $\mu \mathrm{m}$-pore-size Millex filter (Millipore, Bedford, Mass), and placed in vials for subsequent TLC and HPLC analysis as described above. Activities of crude enzyme were determined by monitoring both degradation of substrate and production of the transformed compound.

The expression of target gene was assessed by analysis of total cell protein by sodium dodecyl sulphatepolyacrylamide gel electrophoresis (SDS PAGE) followed by Coomassie blue staining.

Degradation at different temperatures and $\mathrm{pH}$ was also studied to obtain the optimum temperature and $\mathrm{pH}$ for the enzyme. Temperatures considered were $10^{\circ} \mathrm{C}, 20$ ${ }^{\circ} \mathrm{C}, 30^{\circ} \mathrm{C}$, and $40^{\circ} \mathrm{C}$ over a period of $20 \mathrm{~h}$ at $\mathrm{pH} 7.0$ and $\mathrm{pH}$ considered were $5,7,8,9$, and 10 over a period of $20 \mathrm{~h}$ at $30{ }^{\circ} \mathrm{C}$. All experiments were carried out in duplicates. Each experiment was terminated by the addition of $750 \mu \mathrm{L}$ ethyl acetate for extraction of the remaining ZEA and analysis by HPLC.

Degradation of ZEA and its derivatives by resting cells of recombinant $E$. coli

DH5 $\alpha$ harbouring pZEA-4a or pZEA-4b was cultivated in $5 \mathrm{ml}$ of LB supplemented with Ap at $37^{\circ} \mathrm{C}$ with reciprocal shaking $(120 \mathrm{rpm})$, and then $100 \mu \mathrm{L}$ of the culture was transferred to $100 \mathrm{~mL}$ of the same medium. After cultivation at $30{ }^{\circ} \mathrm{C}$ with shaking at $120 \mathrm{rpm}$ until the optical density at $600 \mathrm{~nm}\left(\mathrm{OD}_{600}\right)$ reached 0.4 to 0.5 , isopropyl-1-thio- $\beta$-D-galactopyranoside [IPTG] was added to $0.5 \mathrm{mM}$ and the cells further cultivated at $30^{\circ} \mathrm{C}$ for $15 \mathrm{~h}$. Then the cells were harvested by centrifugation $\left(5,000 \times g, 10 \mathrm{~min}, 4{ }^{\circ} \mathrm{C}\right)$, washed twice with $10 \mathrm{mM}$ Tris$\mathrm{HCL}(\mathrm{pH} 7.6)$ and resuspended in the same buffer to an $\mathrm{OD}_{600}$ of 12 to 13. Mycotoxins (ZEA, $\alpha$-zearalenol, or $\beta$ zearalenol) were added to $5 \mathrm{~mL}$ cell suspension at a final concentration of $100 \mu \mathrm{g} / \mathrm{mL}$. The reaction mixture was incubated on reciprocal shaker at $30{ }^{\circ} \mathrm{C}$. At selected times, samples were centrifuged at $10,000 \times g$ for $5 \mathrm{~min}$, filtered through $0.2 \mu \mathrm{m}$-pore-size Millex filter (Millipore, Bedford, Mass), and placed in vials for subsequent analysis. The culture supernatants were acidified, extracted with ethyl acetate and then analyzed by TLC. The remaining zearalenone was also extracted from the 
supernatants and quantified by HPLC as described previously.

\section{Toxicity Bioassay}

The toxicity of zearalenones and its degradative products were compared by bioassay against Artemia salina based on the method of Harwig and Scott (1971). In the bioassays, groups of 10 to 20 larvae were exposed to a range of concentrations of different zearalenone derivatives in a 96-well microtitration plates. Stock concentration of toxin was prepared as described above. The final concentration of zeralenone, $\alpha$-zearalenol, and $\beta$-zeralenone were $100 \mu \mathrm{g} / \mathrm{mL}$, which were approximately $90 \%$ lethal concentration (LC90) for the larvae. The toxin solutions were then treated with crude enzyme. Groups with only toxins solution in wells served as negative controls, and those with only crude enzyme served as positive control. All treatments were in triplicate and all experiments were repeated three times with plates being in grown at $28{ }^{\circ} \mathrm{C}$ and mortality being evaluated at $28^{\circ} \mathrm{C}$. Complete immobility or paralysis was taken as indication for neurotoxic activity towards the insect larvae.

\section{RESULTS AND DISCUSSION}

The zearalenone-specific transforming enzyme is plasmid encoded

The natural soil isolate $P$. putida strain ZEA-1 has been shown to convert the mycotoxin zearalenone to a compound with low or not toxicity as compared with the parent compound (El-Deeb, 2004). This compound has specific UV spectra $(400 \mathrm{~nm})$ and $R_{f}$ value of 0.09 . Plasmid DNA analysis of Pseudomonas sp. cultures grown on $100 \mu \mathrm{g} / \mathrm{mL}$ zearalenone as sole carbon source indicated the presence of a single large plasmid element (Altalhi, 2007). This plasmid was designated as pZEA-1 of approximately $120 \mathrm{~kb}$ and found to be responsible for ZEA degradation. This was based on the fact that the plasmid cured strain showed ZEA phenotype and the $\mathrm{ZEA}^{+}$phenotype could be conjugally transferred (Altalhi, 2007).

\section{Cloning and localization of ZEA degradation gene in pZEA-1}

Total plasmid DNA isolated from strain ZEA-1 was digested with restriction enzyme $\mathrm{BamH} 1$ and ligated to the positive selection cloning vector, pUC19. Recombinant plasmids were used to transform E. coli $\mathrm{DH} 5 \alpha$, which was then spread on ampicillin-LB agar plates, whereby 1500 colonies were picked and screened for the insert fragment and ZEA degradation in restingcell assays. Analysis of plasmids isolated from the responsible transformed $\mathrm{DH} 5 \alpha$ showed that they all carried $8.6 \mathrm{~kb}$ BamH1 fragment inserted in vector pUC19. One of the plasmid was designated pZEA-2 (Figure 1). Plasmid pZEA-3, which is the same as pZEA-2 except that the $8.6 \mathrm{~Kb}$ fragment is inserted in the opposite direction on the vector, also exhibited the same catabolic activity as pZEA-2 when introduced into $E$. coli $\mathrm{DH} 5 \mathrm{a}$, suggesting that the $8.6 \mathrm{~kb}$ fragment carries the zea degradation gene(s), including their promoter(s).

Restriction mapping of the 8.6-kb BamH1 fragment and further subcloning zea degradation genes

A physical map of the $8.6 \mathrm{~kb}$ fragment showing EcoR1, Kpn1, Pst1, Sph1, and Xba1 sites was generated (Figure 1 ) and used to develop zea gene(s) subcloning strategies. Various fragments were subcloned in pUC19, transferred in $E$. coli $\mathrm{DH} 5 \alpha$ and the transformants were tested by resting-cell assays for their ability to convert zearalenone. By assaying all constructs for the formation of the new product $\left(R_{f} 0.09\right)$ in the medium, it was postulated that the DNA region conferring zea degradation gene(s) activity was found to be located within a $5.5 \mathrm{~kb}$ Pst1Kpn1 fragment (Figure 1). This fragment was cloned into pUC19 and pUC18 to create pZEA-4a and pZEA-4b, in either of the two possible orientations. Both constructs, pZEA-4a and pZEA-4b were transformed E. coli DH5a and screened for the insert fragment and ZEA degradation activity in resting-cell assays. Both constructs were shown to harbour the genes functional for the conversion of ZEA to a new product with an RF value of 0.09 in whole cell assay experiment (Figure 2). This implies that the promoter of the zea gene(s) originating from $P$. putida ZEA-1 is expressed well in $E$. coli strains. This established that the DNA sequences representing the gene(s) encoding ZEA catabolism would in all probability be present within a 5.5 kb Pst1-Kpn1 segment.

To examine whether the subcloned DNA in plasmid pZEA-4a or pZEA-4b expressed zea genes by using expression vector pTE5a, the $5.5 \mathrm{~kb}$ Pst1-Kpn1 fragment was cloned into pTE5a in either possible orientation and create pZEA-4az and pZEA-4bz. Both recombinant plasmids were transferred into $E$. coli $\mathrm{DH} 5 \alpha$ and the transformants were tested by resting-cell assays for the ability to convert zearalenone into a new compound. Both pET5a constructs were subsequently transferred into $E$. coli BL21 (DE3) for expression.

\section{Expression of cloned gene in E. coli}

Expression studies were carried out using E. coli BL-21 (DE3) carrying recombinant plasmid described above. After induction with IPTG or ZEA, crude cell extracts from $P$. putida strain ZEA-1 (pZEA-1) and from E. coli BL-21 (DE3) transformed with pZEA-4az or pZEA-4bz were evaluated for their ability to remove zearalenone. The results in Figure 3 show that the degradation efficiency of crude extract obtained from E. coli BL-21 (DE3) containing (pZEA-4az or pZEA-4bz) was almost identical to that of $P$ seudomonas sp. strain ZEA-1 (pZEA-1) during incubation with zearalenone. No ZEA degradation activity was observed with wild type E. coli BL-21(DE3) (Figure 2). Also, crude extract from $P$. putida strain ZEA-1 and 
from E. coli BL-21 (DE3) (pZEA-4az or pZEA-4bz) converted ZEA $\left(R_{f}=0.64\right)$ into a product that had an $R_{f}$ value of .09 (Figure 2). Under the same condition, extracts from the control E. coli (i.e. without the recombinant plasmid) did not show ZEA conversion activity (Figure 2). Evidence of the expression of zea gene(s) in $E$. coli either driven by the promoters contained in cloned DNA or through the promoter of plasmid vector pTE5a was obtained by cloning of Pst1Kpn1 fragment of plasmid pZEA-2 in expression pET5a vector in either orientation, indicating that cloned DNA has promoter-like sequence that are recognized by $E$. coli RNA polymerase

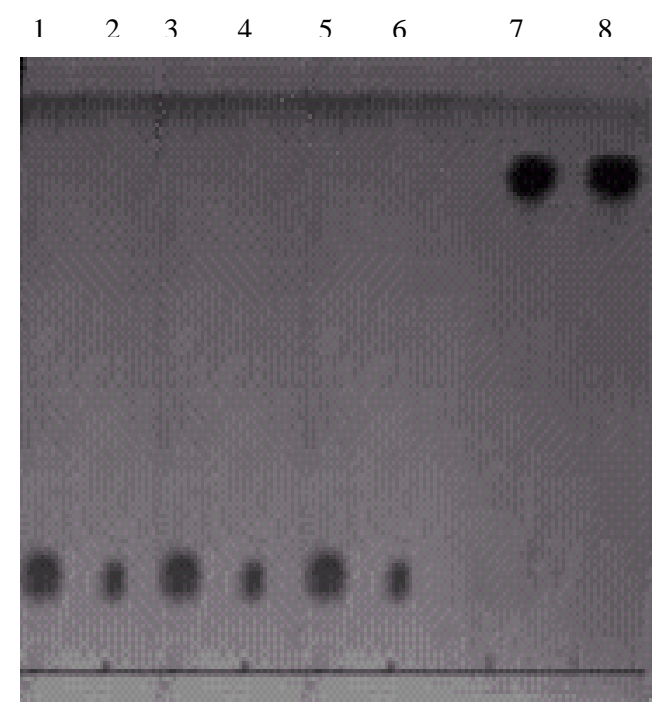

Figure 2: TLC detection of ZEA degradation in a resting cell system and crude extract. Lane 1, ZEA incubated with resting cells of wild type Pseudomonas sp. ZEA-1 (pZEA-1); lane 2, ZEA incubated with resting cells of recombinant E. coli DH5a (pZEA-4a), Lane 3, ZEA incubated with resting cells of recombinant $E$. coli DH5a (pZEA-4b), Lane 4, ZEA incubated with crude extract of $P$. putida (pZEA-1), Lane 5, ZEA incubated with crude extract of E. coli BL21 (DE3) (pZEA-4az), Lane 6, ZEA incubated with crude extract of E. coli BL21 (DE3) (pZEA-4bz), Lane 7, ZEA Incubated with crude extract of wild type $E$. coli BL21(DE3) (plasmidless, ZEA'), and Lan 8, ZEA standard.

Subsequently, the cell extract were then subjected to SDS-polyacrylamide gel electrophoresis. The protein was produced so abundantly in $E$. coli that could be readily visualized in conventional Coomassie blue-stained SDSpolyacrylamide gels. Figure 4 (lane 2) shows the protein profile of $E$. coli Bl-21 containing the plasmid vector pTE5a (negative control). The protein synthesized by strain BL-21 containing recombinant plasmid is shown in Figure 4 (lane 3). The results shown in Figure 4 (lane3) indicate two polypeptides with different molecular weight. This variation in peptides could be attributed to a number of gene products were expressed and involved in zea degradation.

The effect of different temperature and $\mathrm{pH}$ on the loss of ZEA by crude protein extracts of recombinant bacterial strain was also evaluated. After incubation time of $24 \mathrm{~h}$ at $10,20,30,37$ and $50{ }^{\circ} \mathrm{C}$, the residual ZEAcontent were determined as shown in Figure 5. The recombinant strain of $E$. coli showed an optimum at 30 $37{ }^{\circ} \mathrm{C}$. These results are in agreement with results obtained by Takahashi-Ando et al. (2004) who found that the optimum temperature for zea degradation enzyme was $37{ }^{\circ} \mathrm{C}$ and it was rapidly inactivated at $50{ }^{\circ} \mathrm{C}$. Solution $\mathrm{pH}$ also affected the amount of ZEA degraded by crude protein extracts after $24 \mathrm{~h}$. maximum degradation was observed at $\mathrm{pH} 7-8$ (pH levels: 5, 6, 7, 8, and 10), with some ZEA degradation occurring at $\mathrm{pH}$ as low as 5 and as high as 10 (Figure 6) (Smiley and Draughon, 2004). In contrast to our results, TakahashiAndo et al. 2004 found that the optimum pH for the same enzyme is 10.5 . This difference in the nature of enzyme activity towards $\mathrm{pH}$ may be attributed to the different source of enzyme.

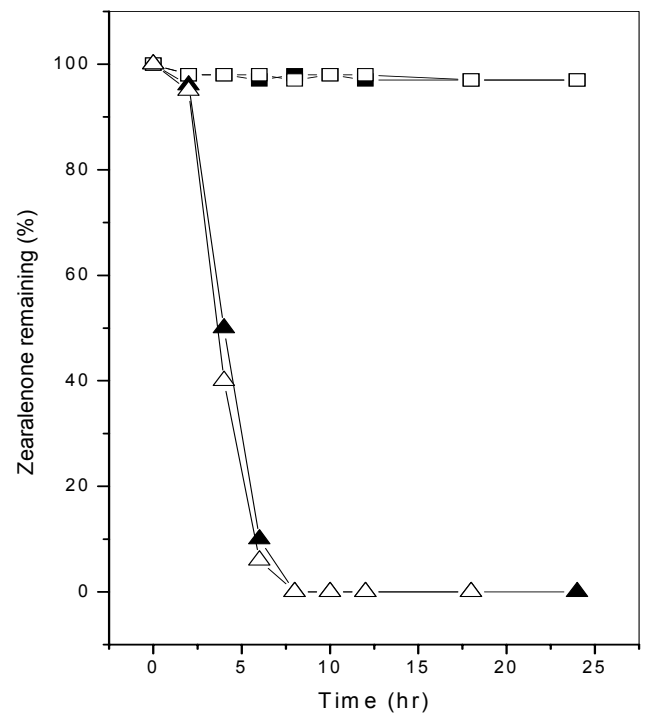

Figure 3: Zearalenone degradation kinitics observed over a period of $24 \mathrm{~h}$ using cell-free extracts of recombinant $E$. coli BL21 (DE3). Cell extracts of $E$. coli BL21 (DE3) (pZEA-4a), $(\Delta)$; Cell extract of wild type E. coli BL21 (DE3), ( $\mathbf{a})$; Cell extracts of P. putida ZEA-1 (pZEA-1), $(\Delta)$, and Cell extract of $P$. putida ZEA-1M (plasmidless), ( $\square)$. Cell extracts were obtained in a sonication process and the remaining of ZEA were measured by HPLC at appropriate time. 


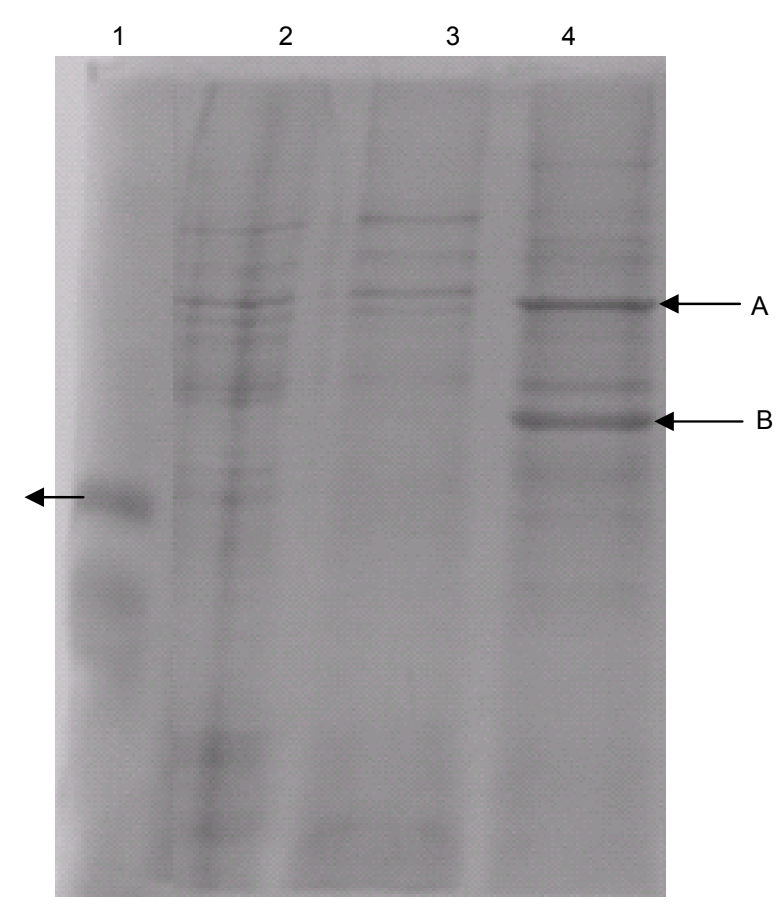

Figure 4: SDS PAGE image exhibiting various protein profiles. Lane 1, size marker; lane 2, E. coli BL-21 containing plasmid vector PTE5a (negative control); lane 3, E. coli BL-21 containing recombinant plasmid

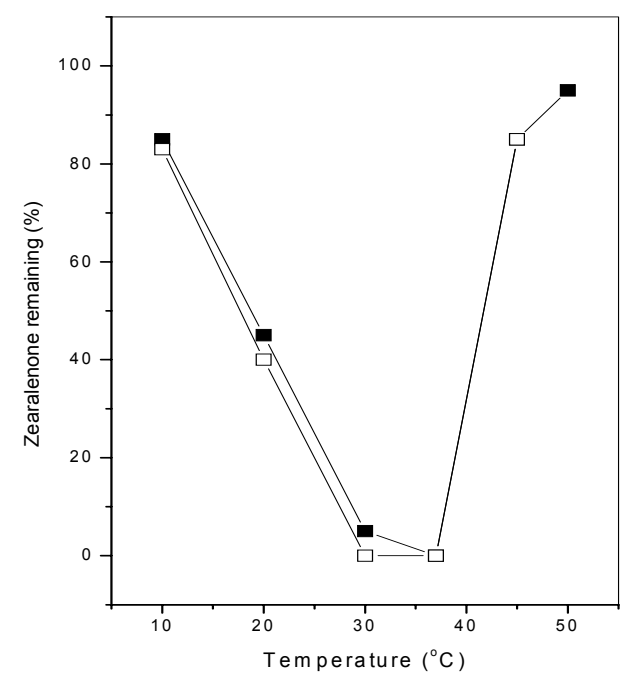

Figure 5: Zearalenone degradation at different temperature using cell free extracts from E.coli BL21 (DE3) (pZEA-4), (-), and $P$. putida (pZEA-1), ( $\square$ ). The reaction was carried out at $25^{\circ} \mathrm{C}, 30^{\circ} \mathrm{C}, 37^{\circ} \mathrm{C}$, and 50 ${ }^{\circ} \mathrm{C}$. The remaining of ZEA was measured by HPLC at appropriate time.

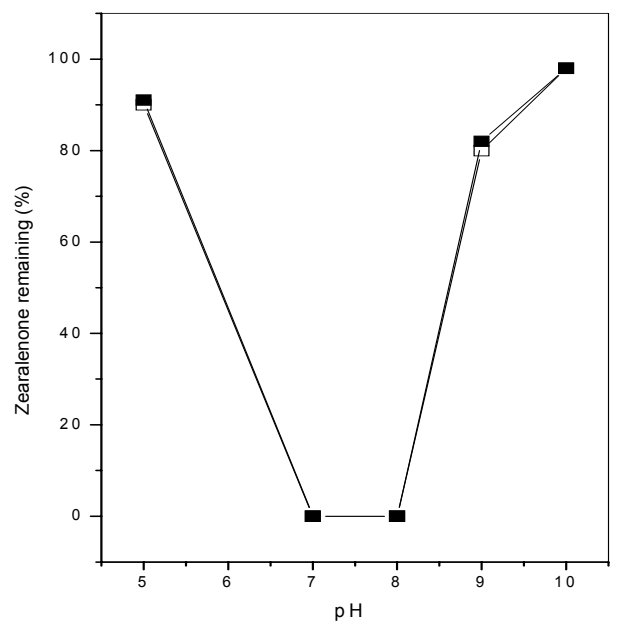

Figure 6: Zearalenone degradation at different $\mathrm{pH}$ using cell free extracts from $E$. coli BL21 (DE3) (pZEA-4), (घ), and P. putida (pZEA-1), (口). The remaining of ZEA were measured by HPLC at appropriate time.

\section{Detoxification of ZEA and its derivatives by recombinant bacteria}

Recombinant E. coli DH5a cells carrying (pZEA-4a) was tested for their ability to remove ZEA and its derivatives from liquid medium (Figure 7). Wild-type or recombinant E. coli cells grown in presence of IPTG were supplemented with $100 \mu \mathrm{g}$ of zearalenone, a-zearalenol, or $\beta$-zearalenol per $\mathrm{mL}$. The wild type bacteria metabolized neither ZEA nor its derivatives, and the mycotoxins were fully recovered as nontransformed from the media (Figure 2), it was not absorbed or adsorbed to bacterial cells (data not shown). On the other hand, an IPTG induced culture of recombinant bacteria carrying pZEA-4 completely removed ZEA and its derivatives from the media. However, the degradation of $\alpha$-zearalenol by recombinant $E$. coli was quite inefficiently compared to the degradation of ZEA and $\beta$-zearalenol. From TLC analysis of supernatant, we were able to detect the degradation product of ZEA with an $R_{f}$ of 0.09 (Figure 2). Takahashi-Ando et al. (2002) cloned and characterized a ZEA-detoxifying gene, zhd101, from fungus Clonostachys rosea which convert ZEA to nonestrogenic product and remove zearalenone and its derivatives from culture media.

\section{Bioassay}

The bioassay was performed three times in triplicate. The results shown in Table 2 represents one of the experiments. Crude enzyme was highly efficient in degrading toxin-allowing survival of larvae at low concentration $(0.1 \mathrm{mg}$ cell protein). Mortality of the test organisms is a sensitive end-point for the assessment of 
the ecotoxicological risk by the environmental pollutants. Accordingly, the microbial biotransformation mediated decrease in the toxicity of the test compounds has been taken as an index of their biological treatment (Lenke et al., 1998). In this study, the toxicity of the residual zearalenone, along with the metabolites formed after their crude extract treatment, was evaluated by using test organism $A$. salina. It was observed that the degradation of zearalenone and its isomers was accompanied by a substantial reduction in their toxicity to the test organisms (Table 2). After 6 and $12 \mathrm{~h}$ of incubation with crude enzyme, 85 to $100 \%$ of larvae survived respectively (Table 2). This finding suggests that the crude enzyme mediates the metabolism of zearalenone and the formed metabolites are less toxic (Kakeya et al., 2002). Accordingly, the crude enzyme can be used for the bioremediation of zearalenones.

Table 2: Approximate survival rates of $A$. salina larvae exposed to toxin solution

\begin{tabular}{|c|c|c|c|}
\hline \multirow[t]{3}{*}{ Toxin } & \multicolumn{3}{|c|}{ Percentage survival of larvae } \\
\hline & Control & $\begin{array}{l}\text { Exposed to } \\
\text { toxin for } 6 \mathrm{~h}\end{array}$ & $\begin{array}{l}\text { Exposed to } \\
\text { toxin for } 12 \mathrm{~h}\end{array}$ \\
\hline & & Enzyme & enzyme \\
\hline $\begin{array}{c}\text { Zearalenone } \\
100 \mu \mathrm{g} / \mathrm{ml}\end{array}$ & 10 & 85 & 100 \\
\hline $\begin{array}{c}\alpha- \\
\text { zearalenone } \\
100 \mu \mathrm{g} / \mathrm{ml}\end{array}$ & 10 & 82 & 100 \\
\hline $\begin{array}{c}\beta \text {-zearalenol } \\
100 \mu \mathrm{g} / \mathrm{ml}\end{array}$ & 10 & 85 & 100 \\
\hline $\begin{array}{c}\text { Degradative } \\
\text { product } \\
100 \mathrm{ua} / \mathrm{ml}\end{array}$ & 100 & 100 & 100 \\
\hline water & 100 & 100 & 100 \\
\hline
\end{tabular}

\section{CONCLUSIONS}

Genes specifying degradation of zearalenone in $P$. putida ZEA-1 was studied for the purpose of understanding their localization in this bacterium. This goal was partially achieved by subcloning the zea genes that specify degradation/detoxification of ZEA from previously reported plasmid pZEA-1 (Altalhi, 2007). The relative position of zea genes expressed in $E$. coli and mapped by restriction enzymes analysis, and the bound aeries of DNA encoding the zea genes were established on $5.5-\mathrm{Kb}$ DNA fragment (Figure 1). Takahashi-Ando et al. (2002) reported similar finding of zea gene cloned from fungus Clonostachys rosea and expressed in E. coli. However, the size and restriction map of zhd101 differed from cloned DNA fragment of the $P$. putida ZEA-1.

Evidence of the expression of zea genes in $E$. coli either driven by the promoters contained in the cloned DNA or through the promoter of expression vector was obtained by cloning the $5.5 \mathrm{~kb}$ Pst1-Kpn1 fragment of plasmid pZEA-2 in expression vector pTE5a. The resulting plasmid, pZEA-4az or pZEA-4bz, expressed zea genes in either orientation, indicating the cloned DNA fragment has promoter-like sequence that are recognized by $E$. coli RNA polymerase.

Comparison of the degradation product by zea genes, which has $R_{f}$ value of 0.09 and UV maxima spectra at $400 \mathrm{~nm}$ (Altalhi, 2007) with a product $\left(R_{\mathrm{f}}\right.$ 0.2) produced by zhd101 gene (Takahashi-Ando et al., 2002) may be attributed to further zearalenoe degradation by zea genes than only cleavage of lactone ring by zhd101 enzyme (Takahashi-Ando et al., 2002). Since more than one proteins induced through growth of recombinant $E$. coli on zearalenoe, this suggests that a number of genes products were expressed and involved in zea degradation. However, the close link between these gene(s) and the fact that we were unable to separate these gene(s) on the $5.5 \mathrm{~kb}$ fragment may indicate that the genes are organized in a complex structure. It is not unusual that degradative genes are clustered in one or more large operons in bacteria (Horn et al., 1991). It has also been suggested that a few common selftransmissible ancestor replicon were involved in the acquisition and spread of different catabolic modules in the environment (van der Meer et al., 1992).

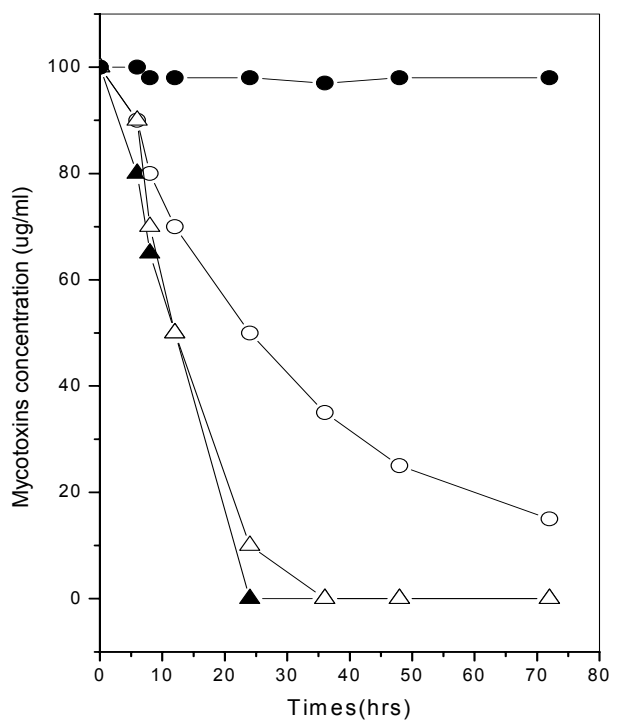

Figure 7: Degradation of zearalenone and its derivatives by resting cells of recombinant E.coli $\mathrm{DH} 5 \mathrm{a}$ (pZEA-4). Mycotoxins were included in MSM medium at a concentration of $100 \mu \mathrm{g} / \mathrm{mL}$. $(\boldsymbol{\Delta})$, ZEA; (o), $\alpha$-zearalenol; $(\Delta), \beta$-zearalenol; and $(\bullet)$, ZEA incubated with no bacteria. The remaining of ZEA were measured by HPLC at appropriate time

\section{REFERENCES}

Altalhi, A.D. (2007). Plasmid-Mediated mycotoxin zearalenone degradation in Pseudomonas sp. ZEA1. Amer. J. Biotech. and Biochem. (3): 150 - 158. 
Chang, A.C.Y. and Cohen, S.N. (1978). Construction and characterization of amplifiable multicopy DNA cloning vehicles derived from the P15A cryptic minplasmid. Journal of Bacteriology 134: 1141 - 1156.

Coe, J.E., Ishak, K.G., Ward, J.M. and Ross, M.J. (1992). Tamoxifen prevents induction of hepatic neoplasia by zearanol, an estrogenic food contaminant. Proceedings of the National Academy of Sciences of the United States of America 89: 1085 - 1089.

Deretic, V., Chandrasekharappa, S., Gill, J.F., Chatterjee, D.K. and Chakrabarty, A.M. (1987). A set of cassettes and improved vectores for genetic and biochemical characterization of Pseudomonas gene. Gene 57: 61- 72.

Ditta, G., Stanfield, S., Corbin, D. and Helinski, D. (1980). Broad host range DNA cloning system for gram-negative bacteria: construction of a gene bank of Rhizobium meliloti. Proceedings of the National Academy of Sciences of the United States of America 77: 7347 - 7351.

El-deeb, B.A. (2005). Isolation and characterization of soil bacteria able to degrade zearalenone. J. Bot. 32: 3 - 30 .

El-Nezami, H., Polychronaki, N., Saminen, S. and Mykkanen, H. (2002). Binding rather than metabolism may explain the interaction of two foodGrade Lactobacillus strains with zearalenone and its derivatives $\beta$-zearalenone. Applied and Environmental Microbiology 68: 3545 - 3549.

Farnworth, E.R. and Trenholm, H. L. (1983). The metabolism of the mycotoxin zearalenone and its effects on the reproductive tracts of young male and femal pigs. Canadian Journal of Animal Science 63: $967-975$.

Green, M.L., diekman, M.A., Malayer, J.R., Scheidt, A.B. and Long, G.G. (1990). Effect of prepubertal consumption of zearalenone on puberty and subsequent reproduction of gilts. Journal of Animal Science 68: 171 - 178.

Grosse, Y., Chekir-Ghedira, L. Huc, A., ObrechtPflumio, S., Dirheimer, G., Bacha, H. and pfohlLeszkowicz, A. (1997). Retinol, ascorbic and \&tocopherol prevent DNA adduct formation in mice treated with the mycotoxins ochratoxin $A$ and zearalenone. Cancer Letters 114: 225 - 229.

Harwig, J. and Scott, P.M. (1971). Brine shrimp (Artemia salina L.) larvae as a screening system for fungal toxins. Appl. Microbiol. 21: 1011 - 1016.

Horn, J.M., Harayama, S. and Timmis, K.N. (1991). DNA sequence determination of the TOL plasmid (pWWO)xyllGFJ genes of Pseudomonas putida: implication for the evolution of aromatic catabolism. Molecular Microbiology 5: 2459 - 2474.

Kado, C.I. and Liu, T.S. (1981). Rapid procedure for detection of large and small plasmids. Journal of Bacteriology 145: 1365 - 1373.

Kakeya, H., Takahashi-Ando, N., Kimura, M., Onose, R., Yamaguchi, I. and Osada. H. (2002). Biotransformation of the mycotoxin, zearalenone, to a non-estrogenic compound by Fungal strain of Clonostachys sp. Bioscience Biotechnology and Biochemistry 66: 2723- 2726.

Long, G.G. and Diekman, M.A. (1986). Characterization of effects of zearalenone in swine during early pregnancy. American Journal Veterinary Research 47: $184-187$.

Megharaj, M., Garthwaite, I. and Thiele, J.H. (1997). Total biodegradaation of the oestrogenic mycotoxin zearalenone by a bacterial culture. Letters in Applied Microbiology 24: 329 - 333.

Pfohl-Leszkowicz, A., Chekir-Ghedira, L. and Bacha, H. (1995). Genotoxicity of zearalenone, an estrogenic mycotoxin: DNA adduct formation in female mouse tissues. Carcinogenesis 16: 2315 2320.

Ruy, D., Jackson, L.S. and Bullerman, L.B. (2002). Effect of processing on zearalenone. Advances in Experimental Medicine and Biology 504: 205 - 216.

Sambrook, J. Fritsch, E.F. and Maniatis, T. (1989). Molecular cloning: A laboratory manual $2^{\text {nd }} E d$. Cold Spring Harbor Laboratory, Cold Spring Habor, NY

Smiley, R.D. and Draughon, F.A. (2004). Preliminary evidence that degradation of Aflatoxin B1 by Flavobacterium aurantiacum is enzymatic. Journal of Food Protection 63: 415 - 418.

Szuetz, P., Mesterhazy, A., Falkay, G.Y. and Bartok, T. (1997). Early telearche symptoms in children and their reaction to zearalenone contamination in food stuffs. Cereal Research Communications 25: 429 436.

Takahashi-Ando, N., Kimura, M., Kakeya, H., Osada, H. and Yamaguchi, I. (2002). A novel lactonohydrolase responsible for detoxification of zearalenone:enzyme purification and gene cloning Biochemical Journal 365: 1 - 6.

Takahashi-Ando, N., Kimura, M., Kakeya, H., Osada, H. and Yamaguchi, I. (2004). Metabolism of zearalenone by genetically modified organisms expressing the detoxification gene from Clonostachys rosea. Applied and Environmental Microbiology 70: 3239 - 3245.

van der Meer, J.R.M., deVos, W., Harayama, S. and. Zehner, A.J.B. (1992). Molecular mechanisms of genetic adaptation in xenobiotic compounds. Microbiology Reviews 56: 677 - 694.

Vargas, J., Peteri, Z., Tabori, Teren, T. and Vagvolgi, C. (2005). Degradation of ochratoxinA and other mycotoxins by Rhizopus isolates International Journal of Food Microbiology 99: 321 - 328.

Utermark, J. and Karlovsky, P. (2007). Role of zearalenone Lactonase in protection of Gliocladium roseum from fungitoxic effects of the mycotoxin zearalenone. Applied and Environmental Microbiology 73: 637 - 642.

Yanish-Perron, C., Viera, J. and Messing, J. (1985). Improved M13 phage cloning vectors and host strains: nucleotide sequence of the M13mp18 and puC19 vectors. Gene 33: 103 - 119. 